Article

\title{
The Water Wars Novel
}

\author{
Hannah Boast
}

Department of English and Comparative Literary Studies, University of Warwick, Coventry CV4 7AL, UK;

hannah.boast@warwick.ac.uk

Received: 18 December 2019; Accepted: 16 July 2020; Published: 5 August 2020

check for updates

\begin{abstract}
Water wars' are back. Conflicts in Syrian, Yemen and Israel/Palestine are regularly framed as motivated by water and presented as harbingers of a world to come. The return of 'water wars' rhetoric, long after its 1990s heyday, has been paralleled by an increasing interest among novelists in water as a cause of conflict. This literature has been under-explored in existing work in the Blue Humanities, while scholarship on cli-fi has focused on scenarios of too much water, rather than not enough. In this article I catalogue key features of what I call the 'water wars novel', surveying works by Paolo Bacigalupi, Sarnath Banerjee, Varda Burstyn, Assaf Gavron, Emmi Itäranta, Karen Jayes and Cameron Stracher, writing from the United States, India, Canada, Israel, Finland and South Africa. I identify the water wars novel as a distinctive and increasingly prominent mode of 'cli-fi' that reveals and obscures important dimensions of water crises of the past, present and future.
\end{abstract}

Keywords: Blue Humanities; environmental humanities; world literature; water wars; water crisis; hydropolitics; cli-fi; postcolonial ecocriticism

\section{Introduction}

'Water wars', it seems, are back. Conflicts from the Syrian and Yemeni Civil Wars to historical and ongoing tensions in Israel/Palestine are regularly framed in policy, media and security contexts as motivated by water and presented as harbingers of a world to come. The return of water wars rhetoric, long after its 1990s heyday, has been paralleled by an increasing interest among novelists in water as a cause of conflict. ${ }^{1}$ There has, however, been little critical attention paid to the literature of water wars. ${ }^{2}$ This may seem surprising when literary criticism has recently undergone a 'hydrological turn' with the emergence of the 'Blue Humanities'. In practice, the Blue Humanities have largely functioned as an equivalent to another emergent discipline, Oceanic Studies, typically neglecting the fresh water essential for the reproduction of human and much nonhuman life. ${ }^{3}$ Criticism on 'cli-fi', or climate fiction, has also proliferated over the past ten years as this phenomenon has entered the mainstream. Narratives of flooding have been a major focus, with floods being 'the dominant literary strategy for locating climate change' (Trexler 2015, p. 82). There has been far less discussion of the parallel scenario, too little water. In this article I catalogue key features of what I call the 'water wars novel', surveying works by Paolo Bacigalupi, Sarnath Banerjee, Varda Burstyn, Assaf Gavron, Emmi Itäranta, Karen Jayes and Cameron Stracher, writing from the United States, India, Canada, Israel, Finland and South Africa. I identify the water wars novel as a distinctive and increasingly prominent mode of 'cli-fi' that reveals and obscures important dimensions of water crises of the past, present and

1 There is a growing body of films concerning hydropolitics and water wars that this article does not discuss, most famously George Miller's blockbuster Mad Max: Fury Road (Miller 2015). See also (Bollain 2010; Kahiu 2009; Rivera 2008).

2 Notable exceptions are Mukherjee (2010) chapter on Ruchir Joshi's novel The Last Jet-Engine Laugh, which anticipated the current 'hydrological turn', and Sharae Deckard's essay 'Water Shocks' (Deckard 2019), with which this piece is in dialogue.

3 This tendency continues an earlier trend noted by Russell McDougall (2012) and Richard Watts (2007), who themselves examine the meanings and politics of fresh water in a Caribbean context. 
future. In doing so, I demonstrate the need for the Blue Humanities to extend its discussion of the privatisation, militarisation and contamination of the world's oceans to its fresh water.

\section{Discussion}

Before discussing water wars in literature, it is worth examining the notion of water wars itself. Water wars may seem inevitable, particularly in arid countries, as climate change and contamination place supplies under ever-greater strain. The likelihood of water wars seems heightened by water's nature as a fundamental human bodily need; our bodies last mere days without it. What is more, many important sources of fresh water cross national borders, including the Jordan, Nile, and Tigris-Euphrates River Basin, making them seem ripe for conflict. The notion of 'water wars' rose to prominence in the 1990s, when then-World Bank Vice-President Ismail Serageldin famously observed that 'many of the wars of this century were about oil, but wars of the next century will be over water' (Selby 2003, p. 49). Serageldin's prediction emerged in a wider climate of fears of resource conflicts exemplified by American journalist Robert Kaplan's notorious 1994 Atlantic article, 'The Coming Anarchy' (Kaplan 1994). This context bears comparison with our present-day environmental moment, in which environmental protection is increasingly cited by the far right as a justification for anti-immigrant politics, and Malthusian references to population recalling Kaplan persist even in mainstream environmental debate (Forchtner 2019). Serageldin's prediction has been echoed more recently in former UN Secretary General Ban Ki-moon's comment that '[c]ompetition between communities and countries for scarce resources, especially water, is increasing, exacerbating old security dilemmas and creating new ones' (Selby and Hoffmann 2014a, p. 361). The notion of 'water wars' seems compelling in the UK amid the apocalyptic rhetoric of 'climate crisis' and 'climate emergency' that has populated mainstream environmental discourse since the rise of the activist group Extinction Rebellion. Nevertheless, political ecologists treat the concept of 'water wars' with greater caution than we might assume from its liberal use in media and policy debates, responding to its revival with surprise and alarm (Cascão et al. 2018). Literary critics may be drawn to the apocalyptic rhetoric of water wars as a way to underline both the urgency of tackling climate change and the continuing importance of the humanities in shaping our response. The effectiveness of our analysis, however, benefits from an awareness of the risks of this discourse.

Predictions of water wars seem intuitively plausible. Geopolitics, however, is not this simple. These predictions are typically founded on the Malthusian assumption that resource scarcity will lead to conflict (Selby and Hoffmann 2012). There is, however, considerable evidence of trans-boundary cooperation over bodies of water, including those cited as a 'water wars' risk, such as the Nile Basin. Highlighting potential conflict over actually-existing cooperation risks exacerbating tensions by seeming to make conflict inevitable. Meanwhile, the tendency to seek out 'water causality' in existing conflicts, as in Syria and Yemen, obscures local causes that may be less immediately comprehensible to metropolitan audiences and policymakers (Selby and Hoffmann 2014b). The Middle East is portrayed as the region most susceptible to water wars, with North Africa next. The willingness to ascribe conflict in these regions to environmental causes reinforces Orientalist stereotypes about the 'irrationality' of their populations, seemingly unable to transcend the determining influence of nature (Selby 2003, p. 51). What is more, it elides the role of the countries of the core in these conflicts, often-particularly in the Middle East-in pursuit of another liquid resource: oil. In this sense the narrative of water wars benefits US foreign policy interests, and it is unsurprising that the US military has played a central role in putting water wars onto the public agenda. Frightening predictions of water wars provide environmental justification for continued military spending on infrastructures at home and intervention abroad, even while the US army remains one of the world's biggest polluters (Belcher et al. 2019).

Water wars discourse has further concerning implications. Headline-grabbing predictions of future water wars divert attention from present-day water inequalities, including water grabs, hydropower development and inadequate water, sanitation and hygiene(WASH) provision. Water shortages are already a reality for the four billion people who suffer water scarcity for at least one month a year 
(Mekonnen and Hoekstra 2016). Such predictions also naturalise water-one of the most abundant resources on the planet-as 'scarce', enabling its commodification and privatisation within dominant market logics that see pricing as the primary scarcity management strategy (Swyngedouw 2005; Selby and Hoffmann 2014a). Political ecology tells us that scarcity is never wholly 'natural', but socially and politically produced - including through privatisation (Linton 2010, pp. 70-72). This derives, of course, from the older geographical insight, lately echoed in scholarship on world-ecology, that 'nature is nothing if it is not social' (Smith 2008, p. 47). ${ }^{4}$ The apparent urgency of water wars scenarios makes them easy to incorporate into new forms of 'disaster capitalism', as scarcity produced by capitalism becomes a new business opportunity to be enfolded into the generation of profit (Klein 2007; Fletcher 2012). Access to fresh water will be a major problem as we move further into a climate-changed future, yet water wars discourse must be treated with caution: at best, it obstructs our understanding of these problems, and at worst intensifies them.

In this article I bring political ecological perspectives on water wars and the water wars novel into dialogue, showing how each illuminates the other. The water wars novel makes visible the dependence of everyday life in the world's core on a ready and taken-for-granted supply of water. The capacity of the novel form to illustrate the phenomenon of combined and uneven development, meanwhile, allows an exploration of the historical origins and wide-ranging impacts of the loss of water that offers, in turn, an indictment of the present. ${ }^{5}$ I show that water takes on a heightened importance in narratives of collapse because of its social, economic and political meanings, including its centrality to the production of the 'modern' city and 'civilised' body. The power of the water wars narrative lies in its gestures towards the global and universal - the threat that the entire world might be drawn into these conflicts-with this tendency echoed in literature by the repeated use of 'global' genres, including near-future apocalyptic or dystopian speculative fictions, young adult novels, and thrillers. I argue, however, that the water wars novel, like water wars discourse, tells us more about anxieties of the world's core and elites about loss of power and status than about geopolitical futures of the periphery. What is more, while origin stories for water wars presented in these novels frequently include critiques of capitalism and consumerism, the water wars novel often serves to naturalise water as 'scarce' and inadvertently bolsters calls for privatisation. I conclude by analysing water wars texts that deconstruct the notion of water as 'naturally scarce', showing water wars as socially produced and offering intimations of alternative 'water worlds' in which water wars are not inevitable.

The best-known 'water wars' novel is Paolo Bacigalupi's The Water Knife, a 2015 science fiction thriller set in a near-future American Southwest that has been devastated by drought. The Water Knife has received greater attention because of Bacigalupi's existing reputation as a prominent, award-winning science fiction writer. Because Bacigalupi's text both fundamentally structures public understanding of the water wars novel and exemplifies its generic and thematic features, I take it as a paradigmatic work deserving of lengthier treatment. In The Water Knife, Bacigalupi imagines a future of US states engaged in legal conflict over water that spills easily into violence, allowing the most powerful states-Nevada and California - to get the water they want. The wealthy have retreated to Chinese-built 'arcologies': expensive, self-contained communities with filtered air, recycled water, sewage composting, farms, and tight security. Those less lucky are left to fend for themselves, often becoming refugees. The novel is narrated by three characters: Angel Velasquez, the 'water knife' of the title, who 'cuts' water to other cities to keep Nevada's flowing; Lucy Monroe, a Pulitzer prize-winning journalist who has become too close to the water crisis for her own good; and Maria, an orphaned, teenage Texan refugee. All are drawn into the hunt for a set of lost late eighteenth-century Native American water rights that promise the owner control over the prized Colorado River and, with it, the capacity to share water for the greater good, or to intensify the inequalities of the present by hoarding it for one's own benefit.

4 See also (Castree and Braun 2001; Harvey 1993; Moore 2015).

5 In this point I draw on the work of the Warwick Research Collective (WReC) (2015, p. 16). 
The Water Knife portrays the twentieth-century superpower of America as a divided, lawless land of water refugees and cloistered elites sustained by Chinese technology. In doing so, it typifies a key theme of the water wars novel: the capacity for water shortages to lead to radical geopolitical upheaval. Water wars novels frequently portray water crisis as a threat to regional and international borders and to the hegemony of the core, a theme found in works by Varda Burstyn, Assaf Gavron, Emmi Itäranta and Cameron Stracher. Itäranta's novel Memory of Water (Itäranta 2014) is set in a future Finland in the aftermath of dramatic climate change and resource wars. Finland has become part of the 'occupied areas of the Scandinavian Union' under the rule of 'New Qian', which controls much of Europe and Asia. Characters live under extreme social repression most evident in their access to water. Stracher's The Water Wars (Stracher 2011) - a young adult text, like many works of cli-fi-is set in a late twenty-first century United States split into six republics, with California on the west, the 'Great Coast' to the east, and the 'Empire of Canada' to the north. All have been at war since Canada dammed the rivers flowing south, prompting the 'Great Panic': riots, wars, the splintering of countries, and 'hundreds of millions' of deaths from disease and malnutrition (pp. 48-49). Gavron's Hydromania (Gavron 2010) imagines a future Israel/Palestine in the aftermath of dramatic climate change, when Palestinians have won the conflict, claimed Jerusalem as their capital and become the regional power, with Israelis becoming refugees or remaining in two crowded coastal cities. ${ }^{6}$ This new world is effectively governed by water corporations from China, Japan, and Ukraine. Finally, in Israeli-Canadian author Varda Burstyn's eco-thriller Water, Inc. (Burstyn 2005), cartoonishly evil American CEO William Greele uses the threat of water wars between American states to push his plan to buy up Quebec's water and redirect it south, exploiting Quebecois separatism and intensifying Canadian fears of US domination. We can understand the repeated appearance of geopolitical reconfiguration in these texts through unpacking the relationship between water and the modern nation-state.

The foundational account of water and the state is American historian Karl Wittfogel's 1957 book Oriental Despotism (Wittfogel 1957). Wittfogel's text is now as notorious for its environmental determinism as for its historical and sociopolitical insights (the historical accuracy of his text is one feature that is often called into question). Nevertheless, it provided an important touchstone for later studies of water and social power, and the dialectical production of nature and society (Linton 2010; Menga and Swyngedouw 2018b; Swyngedouw 2004, 2015). Drawing examples from ancient China, Egypt, India and Mesopotamia, Wittfogel argued that the need for a huge workforce to manage water produced centralised and socially repressive governments, a 'hydraulic society' which he saw as persisting in present-day China and the Soviet Union. While these conclusions show Wittfogel's text as a product of its Cold War context, his identification of water management as fundamental to the consolidation of state power remains important to understanding this process in the present and in the water wars novel. The central role of China in Wittfogel's text, meanwhile, is pertinent to understanding its repeated appearance in the water wars novel as a country able to opportunistically take advantage of water crisis in the core.

Wittfogel may have addressed a much earlier context, yet control of water was central to the staging of the modern nation-state in the nineteenth and twentieth centuries. The construction of large-scale national hydraulic engineering projects in Europe and North America demonstrated the capacity of the state to 'conquer' nature in the service of the new concept of the 'public good', forming part of the phenomenon of 'high modernism' (Scott 1998). Water architectures in the early days of nineteenth-century modernisation were often highly ornamented, becoming 'iconic embodiments of and shrines to a technologically scripted image and practice of progress' in which urban dwellers could achieve an ever-increasing 'emancipation' from nature (Kaika and Swyngedouw 2000, p. 121).

6 Gavron's novel is the only water wars novel I have been able to locate from the region viewed as most vulnerable to water wars, yet it has not been translated into English. This provides further evidence that water in Israel/Palestine is primarily viewed outside the region as a technical, scientific and political issue, rather than a cultural one. See (Boast 2020). For rare discussions of Israeli cli-fi, see (Miller 2013; Yosef-Paz 2018). 
By the mid-twentieth century it was the megadam that had become the icon of 'hydromodernity' (Swyngedouw 2015), a site of 'pilgrimages' for visitors to marvel at humanity's ability to control nature and encounter the power and beneficence of the state (Kaika 2005, p. 3; Blackmore 2018; Worster 1985). Such infrastructural projects also became 'proof' of the coloniser's 'right' to rule and a marker of Europe and America's 'higher' stage on a teleological path of technological progress, as in British author B. S. Johnson 1964 experimental novel Albert Angelo:

But Albert paused! A tap dripped in the sink behind the counter. Albert thought with awe of the vast resources behind that tap: the miles of pipes, of mains, the reservoirs, the rivers, the rain. He imagined with what awe an African immigrant must regard the water supply: "It comes in pipes, you just have to turn a tap thing, man. And that same water is the same as the Queen drinks. When I turn that tap thing, man, I'm connected with the same water she uses. And the sewers, man, they connect, too, she don't use no special sewer, they all connect up and side by side hers and mine come out at Barking Creek. That's a democratic country for you, man." (Johnson [1964] 2013, pp. 129-30)

While these lines are intentionally humorous, it is clear that, for Albert, England's water infrastructures embody its technological sophistication and superiority to a generic 'Africa', at the same time as underscoring the country's apparent commitment to equal provision for all its citizens. Such 'superior' infrastructural programmes were (and still are) presented as a 'gift' bestowed on colonised countries, while after independence hydraulic projects were resignified as marking a newly-decolonised nation's arrival on a world stage, even as they entrenched new forms of colonialism through development loans (Gilmartin 1994; Nixon 2011, chp. 5; Gandy 2004, p. 371). Water, then, is deeply connected to the production and contestation of the modern nation-state.

As Johnson suggests in his reference to a 'democratic country', water is central to the production of modern liberal citizenship. This is similarly pertinent to understanding the water wars novel. Political ecologist Anand (2017) uses the term 'hydraulic citzenship' to capture the relationship between a domestic water connection and national inclusion, with water materially and metaphorically connecting members of a national community while offering evidence of their protection by the state. From the development of domestic water infrastructure in nineteenth-century Britain onwards, this process created new codes of bodily conduct through which citizens could further separate themselves from nature and from each other (Kaika and Swyngedouw 2000, p. 126). Transcending the sphere of bodily influences was thought crucial to the ability to exercise the rights of the ideal liberal subject within modern capitalist society (Otter 2002). As Matthew Gandy writes, 'the plumbing of the metropolis was thus a process of both physical reconstruction and social engineering' (Gandy 2004, p. 367). Importantly for the purposes of this article, this extends to a global stage on which 'cleanliness' is taken as an index of 'civilisation', 'innate' difference and the ability to self-govern.

The relationship between water, the nation-state and citizenship is central to the water wars novel. It suggests that one of its key themes is anxiety about the 'undoing' of modernity in the core, and the destabilisation of the developmentalist hierarchies that have served to 'justify' its hegemony. In many cases the visions of devastated cities of the core in the water wars novel bear an eerie resemblance to countries of the periphery, portraying an effective reversal in global power relations occasioned through the loss of water. While such jarring visions may prompt the shock needed to cause readers to follow a novel's prescriptions, they point to a way that the water wars novel, like water wars discourse, is less-than-helpful. As Wenzel (2020, p. 31) observes of eco-apocalypse narratives, these frequently fail to recognise that 'one person's apocalyptic future is another's precarious present.' Such narratives carry older imperial temporal anxieties that evoke Kaplan's 'coming anarchy' spiralling from periphery to centre, at the same time as instantiating colonial assumptions about water, cleanliness and civilisation. In doing so, the water wars novel can obscure the environmental injustices of the present and foreclose potentially liberatory hydropolitical imaginaries of the future, including the solidarities rather than antagonisms that might derive from the need for water. 
This process of anxious evocation is present in our texts. Itäranta's characters fear giving tap water to their children 'even if it's been boiled', while 'travelling water merchants' swindle the thirsty by selling salt water that costs 'most of their budget for the week' (Itäranta 2014, pp. 16-18). The novel's central tension concerns a hidden spring and illegal infrastructure with which the protagonist's family supplements their allotted supply, defying New Qian's ruthless water enclosures. Stracher and Gavron similarly portray tensions over water enclosure, this time through privatisation, with their protagonists seeking to reduce water inequality by developing technology that circumvents corporate control (a project that Gavron's protagonist, Maya, whose name optimistically evokes the Hebrew word for water, mayim, ultimately abandons to pursue personal wealth). These problems are markedly similar to existing difficulties over water access in the periphery, where improvised arrangements are common in contexts of inadequate or nonexistent state provision. Itäranta's scenario evokes, for instance, water access in Gaza, where tap water is largely undrinkable, with buying expensive, potentially contaminated water from private sellers the only option (Efron et al. 2018, p. 33). These portrayals of state and corporate enclosure of springs and technology recall, meanwhile, Israel's legal and bureaucratic control over the Palestinian ability to drill new wells in the West Bank, or the role of corporations in restricting rather than opening up water access in post-apartheid South Africa (Dajani 2014; McDonald and Ruiters 2005).

A similar dynamic animates Bacigalupi and Burstyn's novels. In Bacigalupi's The Water Knife, America has become the site of a water refugee crisis, reliant on international aid and populated by a mobile cohort of humanitarian workers. Bacigalupi describes the arrival of 'USAID. Salvation Army. Red Crescent drought specialists. Doctors Without Borders. Red Cross', in a monotonous list that underscores America's new position as a site on the global circuit of humanitarian crises (Bacigalupi 2015). The reference to 'Red Crescent drought specialists' indicates the reversal of America's status, with aid now travelling from the primarily Muslim, Middle Eastern and North African countries usually portrayed as susceptible to water wars to the US. Mexico's water-induced disintegration into 'the Cartel States' offers a frightening vision of America's future. As Angel says, 'Countries [ ... ] They come and go' (Bacigalupi 2015, p. 232). In Burstyn's Water Inc., Greele devises a system of pipes, ports, canals, dams and roads to extract Canada's water that mirrors the infrastructures of oil extraction in Canada and the world's peripheries, while Canadian politicians are haunted by fictional events in Oaxaca, Mexico, with the city council fined twenty million dollars under the North American Free Trade Agreement (NAFTA) for refusing to allow a US corporation to build a new petrochemical plant (Burstyn 2005, p. 37). Quebec's environment minister, Lalonde, fears he has little choice, suspecting (correctly) that the US government will use NAFTA and World Trade Organisation rules to push through the project (Burstyn 2005, , pp. 23, 153). Quebec in particular is weak because of its economic position alongside the world's periphery and semi-periphery, with Lalonde 'competing hard for capital against the likes of Myanmar, China and Vietnam' (Burstyn 2005, p. 65). Geopolitical anxiety is heightened in Gavron and Burstyn's texts by Israel and Canada's locations on the fringes of the core, with water wars potentially leading to the loss of a status gained only recently. The water war, crucially, plays this disconcerting role because of water's fundamental place in the production of the modern nation-state and its citizens, and in marking the borders of 'civilisation' and 'modernity'.

There is, however, an alternative reading of these reversals. Placed alongside this context of water inequalities in the periphery, we might read these texts as highlighting world water struggles rather than portraying a threatening 'reversion' of the core to the conditions of the periphery. In this sense, the transformations in these texts might be said to enact the 'cognitive estrangement' identified by Suvin (2016) as characteristic of science fiction, defamiliarising the ordinary in order for it to be seen anew. This would render them 'critical dystopias', or, in Tom Moylan's words, literature that 'adopt[s] a militant stance that is informed and empowered by a utopian horizon that appears in the text-or at least shimmers just beyond its pages', in this case a broader concern for water justice (Bambini 2019). Gavron's text might seem a likely candidate for this reading given the well-known history of contestations over water in Israel/Palestine. We might see Hydromania as highlighting the territorial 
and water injustices of Palestine's present through displacing them onto Israeli citizens. The novel was, however, largely received as a critique of Israeli 'values and habits in the present' and a warning about its future, with a Haaretz reviewer counselling readers to 'enjoy the overt aspect of the story without searching for some covert, critical and overly harsh statement about the human experience' (Malka 2008). A blogger similarly portrays Hydromania as an enjoyable retreat from the present-day conflict, observing that '[i]t is not surprising to see current political issues taking a back seat in a science fiction thriller' (Kaminski 2009). Itäranta's emphasis on the evils of consumerism, encapsulated in the 'plastic grave' where Noria and her friend Sanja scavenge for thrown-away 'treasures' that are 'fairly intact or easily repaired', similarly works against a reading of Memory of Water as highlighting existing water inequalities by foregrounding individual responsibility rather than structural conditions (Itäranta 2014, p. 22). While the Haaretz review of Gavron represents a specific Israeli myopia about the realities of the occupation, these instances show a wider tendency for the water wars novel to evoke the hydropolitics of the periphery as a threat while obscuring the injustices of the present.

These 'temporal anxieties' about the rolling-back of the hydrological preconditions of modernity are underlaid by a parallel anxiety about the rise of China also figured in hydrological terms. As Sharae Deckard observes, these works regularly depict 'the crisis of the neoliberal hydrological regime [... ] through outward-looking discourses of China as simultaneously technotopian and hydrocolonialist', portraying a 'Chinese empire imagined as hegemonic as a result of its production of new ecological fixes' (Deckard 2019, p. 122). This theme is evident in Bacigalupi and Itäranta's texts, both of which incorporate Chinese words to indicate China's cultural, as well as political and economic, ascendancy, seen in Bacigalupi's use of yuan rather than dollars, and Itäranta's references to the 'liang' as a unit of weight (Itäranta 2014, p. 83). Chinese hegemony is apparent in The Water Knife through the 'arcologies', built by Chinese investors with Chinese technology, while in Memory of Water the renaming of Russia's capital Moscow as 'Mos Qua' indicates the scale of Chinese domination (while also showing the at-times troubling way in which Itäranta melds 'Oriental' cultures) (Itäranta 2014, p. 46). Itäranta's preoccupation with China may seem surprising given Finland's history of being occupied by its powerful neighbour, Russia-itself known for massive national water infrastructure projects-and the re-emergence of Cold War tensions between Russia, Europe and the US, notably since the 2016 US election. How, then, can we understand the primacy of China in the water wars novel?

Contemporary geopolitics and the work of Wittfogel help to explain China's prominent position in these texts. The pillar of current Chinese foreign policy is the 'Belt and Road Initiative' (BRI), a state-funded strategy to renew the Silk Road route between China and Europe with an enormous network of Chinese-built infrastructure. This project is feared in the core for its potential to increase Chinese influence and criticised in the periphery for its capacity to produce a new colonialism by trapping countries on the route with debt. The portrayal of China's technological success in these novels echoes present-day fears in the core of its expansionist international ambitions, with China seeming poised to exploit environmental crisis and a core typically depicted as mired in a refusal to recognise climate change. Wittfogel's notion of the 'hydraulic society' is also crucial to reading these texts. The highly hierarchical world of the water wars novel echoes Wittfogel's older concept, of which China served as paradigmatic example. Fears of Chinese power, then, have long been associated with the control of water, with these fears encoding a wider symbolic imaginary of water as an unstoppable, irrational, faceless force shared by these contemporary texts and an older Sinophobia. The water wars novel draws attention to two sharply contrasting associations between water and political power: one in which state control of water leads to authoritarianism, another in which control and distribution of water is central to the production of the modern citizen of liberal democracy. This clash indicates the capacity of water wars texts to channel key tensions in the political imaginaries of water.

The water wars novel frequently prompts its reader to reflect on the present-day conditions that have led to their imagined scenario, often aiming its fire at capitalism and consumerism. Bacigalupi offers the sharpest critique of the present, depicting the US as a site in which corporate opportunists seek to profit from disaster just as they might descend on a peripheral extraction zone: 'Chinese investment 
bankers from the Taiyang, down out of their arcology and slumming. Halliburton and Ibis execs, doing water prospecting, insisting that they could frack aquifers into gushers if Phoenix would just foot the bill. Private security guards off duty and on. Bureaucrat-level narcos' (Bacigalupi 2015, p. 28). His most pointed creation is the arcologies, self-enclosed systems with advanced environmental technology that nevertheless perpetuate the inequalities of the novel's world, highlighting the limitations of the 'green capitalism' and 'green growth' touted lately in the core by governments and entrepreneurs. Bacigalupi's jarring juxtapositions of the arcologies with Maria's slum home and accelerated vision of globalised extractivism forms part of his staging of the origins of water shortages in the uneven and combined development of the capitalist world-system. Without an end to capitalism, Bacigalupi suggests, green tech offers little promise.

The arcologies, Itaranta's tea master's ceremonies, and Gavron and Strachey's open-source technologies offer what Deckard describes as 'intimations of alternative conceptions of water that refuse the instrumentalist epistemes of sink, commodity, input and object that have precipitated hydrological exhaustion' (Deckard 2019, p. 122). Nevertheless, these texts feel remarkably pessimistic, a product of the universalising rhetoric and imagery that often recur in discussion of water. This inhibits their analysis of the present at the same time as unhelpfully portraying water wars as inevitable. In Bacigalupi's text this tendency appears to derive from Mark Reisner's 1986 Cadillac Desert, a key influence on the book that achieves totemic status for its characters, and from Bacigalupi's noir aesthetic. Reisner tells the story of water in the American West as one not just of greed, but human nature: a 'yearning to civilize' the desert and an 'instinct that followed close on the heels of food, sleep, and sex' (Reisner 1986, pp. 14-15). Bacigalupi offers a similarly pessimistic view of human nature through his character Angel, whose view that '[s]ome people had to bleed so other people could drink' is ultimately affirmed in the novel's concluding twist (Bacigalupi 2015, p. 364). Bacigalupi also borrows from Reisner his allusions to the ancient Hohokam civilisation, which developed sophisticated irrigation systems in central Arizona before meeting a mysterious end. In spite of his conscientious depiction of the capitalist causes of water crisis, Bacigalupi offers this as a vision of Phoenix's future that deterministically affirms exhaustion of water as a universal human trait (Bacigalupi 2015, p. 345; Reisner 1986, pp. 264-66). Such a narrative echoes predictions of water wars that share an 'underlying assumption [ ... ] that sooner or later humans will have to engage in a war against droughts, as if the latter were driven by some sort of divine or natural process over which humans have no control' (Menga and Swyngedouw 2018a, p. 1), an assumption which this article, following work in political ecology, contests. I turn now to two water wars novels set in countries of the semi-periphery which we might see as representing the states of affairs these texts fear arriving in the core as a result of water shortages. In different ways, however, Karen Jayes' For the Mercy of Water (Jayes 2012) and Sarnath Banerjee's All Quiet in Vikaspuri (Banerjee 2015) refuse this narrative of inevitability, using imaginaries of water wars to offer contrasting diagnoses of the present that gesture towards alternative water futures.

For the Mercy of Water is set in the near future in an unnamed country that resembles Jayes' home of South Africa. The country is suffering from a severe drought that has led to a seemingly endless 'water war', and to the privatisation of water and other social services. Water is managed by 'the company', an unnamed, foreign-owned multinational whose 'guards' brutally suppress illegal attempts to access water. The government hires 'experts' who present water saboteurs as 'fratricidal, religious' and motivated by violence 'deeply rooted in their history'. The country is divided between the affluent cities-where water consumption is largely unhindered-and the countryside, which has emptied as men have moved to the cities to find work that will pay their water bills. Those left behind are communities of girls cared for by powerful grandmothers, known for their skill in tapping the pipes. The novel is set during a rare rainfall in a remote, abandoned village, as the 'company men' rush to 'secure' the water. We follow an unnamed journalist as she investigates a story of mass rape of village girls by company guards, while reckoning with her own experience of sexual violence at their hands.

Jayes' novel shares many features with the texts discussed above, notably pessimism about privatisation. It is set, however, in a context in which scarcity is an existing threat, with Cape Town 
narrowly avoiding 'Day Zero' in 2018. The violent imposition of privatisation, too, is a recent memory. South Africa's African National Congress (ANC) government came to power in 1994 on a promise of extending infrastructural provision to those denied services under apartheid, as part of redistributing national wealth. Apartheid-era policy had prioritised delivering water to (mainly white) urban users, agriculture and industry, neglecting predominantly black townships, informal settlements and rural areas, a division echoed in Jayes' racialised rural/urban divide. By the mid-1990s, 12 to 14 million mostly black South Africans, of a total population of around 40 million, lacked adequate water, while 18 to 20 million had no access to sanitation services (Bakker and Henson 2000). Very quickly, however, under pressure from the World Bank and International Monetary Fund, the ANC turned water over to the private sector, cutting funding to councils and initiating public-private partnerships with multinational water corporations that inflated prices (McKinley 2005). Jayes' portrayal of the 'company' and its racialised water distribution evokes this history, highlighting in turn its legacies in differential experiences of the recent drought that were largely absent from mainstream coverage. ${ }^{7}$ Her references to sabotage and hijacking similarly echo the South African anti-privatisation movement (von Schnitzler 2008). Jayes' attention to gender, meanwhile, evokes both South Africa's history of endemic sexual violence and the role of water management practices in producing and contesting gendered and racialised subjectivities (Sultana 2009, p. 428).

It is Jayes' concern for gender, race and water that forms the basis of her alternative account of water wars and vision of alternative water relations. ${ }^{8}$ For the Mercy of Water is an ecofeminist text, highlighting common patterns of domination in the exploitation of women and nonhuman nature. ${ }^{9}$ While Jayes' approach bears the risks of essentialism often found in ecofeminist writing, it also offers a way of re-scripting the gender relations produced through struggles over water. Jayes identifies patriarchal modes of masculinity as the common source of the expropriation of water and sexual violence through the guards, as well as in the scene in which the unnamed narrator is raped, when she is described metaphorically as becoming water: 'as if he was moving on top of a smooth dark spill.' At the same time, Jayes aligns women with uncommodified water through 'Mother', a village grandmother who steals water for the village girls and cares for them after assaults by the guards. Instead of seeking revenge, however, Mother understands the enclosure of water in biopolitical terms, as 'a war over our bodies, a war over every piece of life in all of us'. It is on this basis that she shows mercy to a vulnerable soldier:

A large part of me is convinced that I must be killing this man [ ... ] But then I am seeing the soldier's face with the eyes that are pools of blood. And this blood from his eyes is running down from his head and it is running into Noni's blood, and they are running together into the water [ ... ] I am thinking that the human body, it is mostly water. And I am seeing in this blood and water and the way he is lying blind, that we are busy down here fighting a war over our bodies.

This passage instantiates a different symbolic register for water to the texts discussed so far. Instead of causing conflict, water becomes healing and connective: ' $[t]$ he water that is holding the forgiveness and promise of clouds, the water that is a gift from God and not a reason for war.' Jayes further gestures towards earlier, non-instrumentalised modes of relating to nonhuman nature through

7 'Day Zero' was often characterised in critical coverage as a 'middle and upper-class problem', since poor black residents of Cape Town have long experienced water shortages. See (Walton 2018).

8 In discussing gendered violence alongside water privatisation in South Africa, Jayes' novel bears comparison with Emma Ruby-Sachs' The Water-Man's Daughter, in which a Canadian water executive rapes a local girl and is subsequently murdered, with anti-privatisation activists put under suspicion. I do not discuss this novel here as it is not framed in the context of water wars, but a reading of the two novels can be found in Dunn (2016).

9 Ecofeminist themes also appear in Hydromania, Memory of Water and The Water Wars and, to a lesser degree, The Water Knife, through the concern of their female, often young, protagonists for more sustainable ways of living with water. The relationship between ecofeminism and hydrofiction deserves greater exploration but goes beyond the limits of this piece. 
Mother's collection of herbs, bones and medicines, associating the commodification of water with white, masculinist domination.

Aesthetic and generic choices in the novel similarly suggest alternative water relations. ${ }^{10}$ Mother tells her story in elliptical fragments, resisting the linear, implicitly patriarchal language demanded by the company's medical professionals that is echoed in their rationalisation of the country's water. The novel is certainly recognisable as an 'extrapolative' dystopia in a similar way to other water wars novels, taking elements of the present to produce a world of the future (Seeger and Davison-Vecchione 2019). However, Jayes also includes lengthy, realist descriptions of nonhuman nature that are incongruous within this science-fiction-dominated genre, as in the narrator's account of a storm, where human presence seems entirely absent. Jayes writes: 'There was no other sound but the rain, like stones knocking softly over wood, and there was no other smell but water and moist soil and wet grass, and the first gurgles of tiny, infant rivers between the rocks.' These attentive descriptions of nonhuman dynamics of flow, growth and slow but constant change contrast with the recurring portrayal in mainstream water wars texts of nature as a violent threat or cause of conflict, challenging their projection of the inevitability of water wars. The novel's allegorical register, lacking names of people or places, similarly contrasts with the elaborate world-building of the water wars novel, which heightens the sense of a world one step away from ours but largely reproduces dominant narratives of water conflict. These distinctions help Jayes to model alternative relations of water that both complicate these narratives and challenge the ways that water management strategies produce structures of gendered and racial oppression. This version of the water wars novel seems, however, less marketable in the countries of the core: while For the Mercy of Water won the 2013 South African Sunday Times Fiction Prize, it is only available outside South Africa as an eBook, suggesting that narratives of environmental destruction are more saleable.

Banerjee's All Quiet in Vikaspuri, a graphic novel set amid the fictional 'water wars' of Delhi, similarly emerges from a semi-peripheral context in which water shortages are already a pressing concern. ${ }^{11}$ Its protagonist, Girish, is an unemployed plumber who moves to Delhi in search of work after his employer 'Bharat Copper Limited', a fictionalised version of India's Hindustan Copper Ltd., is sold by the Indian government to an Australian multinational amid falling copper prices (Banerjee 2015, pp. 7-8). Girish swiftly loses his job as the 'Platypus Group' seeks to remove troublesome workers who contest its record on workers' rights and its pollution and over-abstraction of local water. He finds a new role searching underground for the mythical Saraswati river, working for a shady entrepreneur, Rastogi. Underground, Girish chances, Dante-like, upon people exiled for the crime of wasting water, then on his emergence discovers that Delhi has been consumed by a 'water war'. The war has in fact been manufactured by Rastogi, who plans to acquire Delhi property at knock-down prices; sell exclusive apartments in Gurgaon, a city 30 kilometres from Delhi built almost entirely by private companies, to wealthy fleeing Delhiites; then end the war and sell his Delhi portfolio for a huge profit. Unlike texts discussed in the first half of this essay, where water wars are an outcome of the deterministic forces of natural scarcity, human nature and capitalism, Banerjee's water war is entirely manufactured, with his text emphasising that scarcity is not a natural condition, but socially and politically produced. In doing so, Banerjee's novel avoids inadvertently affirming the logic of privatisation that is so frequently an outcome of the water wars novel.

Banerjee's text, like Jayes', diverges from the stylistic conventions of the water wars novel in ways that sharpen its critique. In extrapolating from India's present-day water shortages, ongoing neoliberal experiment and Hindu nationalist revival, All Quiet in Vikaspuri is a dystopia, the most common mode of the water wars novel. Still, as with Jayes close, if allegorical, attention to South Africa's recent water history, Banerjee's text is resolutely grounded in an Indian context. In this way

10 On style and hydropolitics in For the Mercy of Water, see also Harris (2020, chp. 4), which was published as this article was going to press.

11 See (Birkinshaw 2017). For a more detailed analysis of Banerjee's hydropolitics, see (Madan 2018). 
his work avoids the universalising framework of many water wars novels that presents water wars as inevitable, even if, as with Jayes' novel, this framing may also explain why All Quiet in Vikaspuri was not published outside India in spite of its topical subject. Banerjee includes untranslated Hindi, Urdu and Bengali, and acronyms and references to Indian myth and popular culture that would be largely unfamiliar to non-Indian readers. These are often combined with British and American cultural references, notably in a section consisting solely of splash page advertisements that visualise Delhi's 'water war' through 'Indianising' titles of popular war films, including 'Bridge on the River Yamuna' and 'Saving Private Arora' (the title of the book itself is, of course, also borrowed, from German author Erich Maria Remarque's 1929 novel). The multilingual and transnational nature of these references echoes the jarring combinations of languages and cultures found in Bacigalupi's text, which in both cases evoke the spatial and temporal ruptures occasioned by the effects of uneven and combined development. Banerjee, however, avoids references to shortages throughout human history, instead locating their causes solely in political processes. He depicts the efforts of multinational corporations, financial institutions and local elites to promote economic liberalisation and 'short-termism' (Banerjee 2015 , p. 51), with these forces ultimately serving to extract wealth and inflict social and environmental devastation felt acutely by the poorest, like Girish. Banerjee roots these phenomena in longer processes of colonial extraction through naming the financial institution that raises the funds for Platypus to buy Bharat Copper Limited 'Fraser and Clive', suggesting the history of the East India Company. At the same time, Rastogi's search for the Saraswati to sell its water situates the book in the context of ongoing Hindutva efforts to prove Hindus the indigenous inhabitants of India, a trend that has paralleled and intensified the neoliberal turn in which Rastogi is similarly invested (Chacko 2019). Banerjee's collage of styles and references grounds the novel in global financial and political processes and in its local context. In doing so, his text refuses to naturalise wars over water and offers a crucial counterpoint to mainstream water wars novels and rhetoric.

The graphic novel form plays a further crucial role in Banerjee's alternative vision of water wars. Graphic novels foreground questions of representation through combining image and text, making them well-placed to challenge orthodox framings of social and political issues. As visual works with their own architectures of panels and gutters, they similarly invite consideration of the reshaping of geographies produced by resource extraction and expropriation. ${ }^{12}$ A strength of the graphic novel in this regard is its capacity to 'fracture both time and space, offering a jagged staccato rhythm of unconnected moments' that the reader must assemble into a narrative through the process of 'closure', or mentally filling in the gaps between panels (McCloud 1993, p. 67). The graphic novel can inscribe processes of temporal disruption, acceleration and inheritance spatially, allowing it to register the non-linear unfolding of environmental harms across different geographies (Perry 2018) and to highlight patterns of causation that would risk feeling forced in solely written form. In All Quiet in Vikaspuri, for instance, Banerjee includes a full-page panel depicting an austere megadam towering over a reservoir, with a small, brief caption in the top left corner and a drowned village at the bottom (Banerjee 2015, p. 56). The single shade of blue used for the water dominates the lower half of the page, presenting the reservoir as a 'dead' space and emphasising the environments and communities sacrificed for what the caption describes as 'unjustifiably low amounts of electricity'. The panel itself is not immediately relevant to Delhi's 'water wars', yet its huge size indicates significance. A reader must deduce its meaning as part of a longer historical narrative of hydromodernity, neoliberalism and uneven development in twentieth and twenty-first century India, with the caption's brevity and peripheral placement indicating the marginalization of dissenting voices. The drowned village's small, almost hidden well, with its bucket swaying in the current, evokes alternative and suppressed ways of living with water. The formal possibilities of the graphic novel thus allow Banerjee to offer a counterpoint to the simplifications of mainstream water wars narratives.

12 Thanks to an anonymous reviewer for prompting me to consider this aspect of the text further. 
Banerjee and Jayes offer valuable diagnoses of the present and gesture towards older, more sustainable ways of living with water. Both, however, share a limitation found across water wars texts: the failure to show in any substantial sense what a future beyond water wars would look like. ${ }^{13}$ The novels end unsatisfyingly, with Jayes offering a quasi-spiritual account of natural renewal informed by her Muslim faith and by a somewhat idealistic vision of a post-Truth and Reconciliation Commission renewal of South Africa. ${ }^{14}$ '[F]or the mercy of water', Jayes writes, 'the life is still here'. While elsewhere in the text Jayes highlights the political origins of water wars, her conclusion is strangely disempowering, as if all that must be done is wait for nature to return. Banerjee's text ends with a confusing list of events narrated partially through Girish's memoir, including the conclusion of the war and death of Rastogi, Girish's emergence as a celebrity, and the seeming solution to Delhi's problems, the creation of a 'new programme called Girish Jal Vitaran Yojana for equitable distribution of water' by the Delhi Jal Board (water utility) (Banerjee 2015, p. 141). The future of Delhi's water is spelled out in just a single frame, which may imply the inadequacy of a bureaucratic solution. However, this lack of a real sense of what happens next suggests that both texts are ultimately unable to imagine a way of resolving the contradictions they highlight. They share this feature with Bacigalupi and Itaranta's texts, which similarly end on an indeterminate note at a pause between events. The recurrence of this ending suggests a structural limitation in the water wars form. As such, while the water wars novel may be a helpful diagnostic, we may want to look to other literary forms — such as, as I have suggested elsewhere, hydropoetry (Boast 2020)—to imagine substantive post-capitalist water futures.

\section{Conclusions}

The water wars novel is an increasingly prominent form of cli-fi that has emerged in tandem with the revival of water wars discourse in media and politics contexts. In this article I have surveyed a range of water wars texts, identifying a common tendency for these works to become a vehicle for imperial anxieties about a reversal in global power relations between the core and periphery. The wide-ranging symbolic meanings of water differentiate the visions of the future found in the water wars novel from the depictions of ruined cities and social collapse found in cli-fi more broadly, with water standing in for urban modernity, democratic citizenship and the assumed superiority of the core. This article has shown that water also holds contradictory meanings in political imaginaries that can be challenged and changed by literary representation, notably when water wars texts from the periphery and semi-periphery are put in dialogue with works from the core. Water wars predictions and water wars texts sit in a recursive relationship, with each appearing to reaffirm the explanatory value and prophetic force of the other. For these reasons, the water wars novel is necessary reading in both social sciences debates on the phenomenon itself and in future articulations of the Blue Humanities.

Funding: This research was funded by the Leverhulme Trust (ECF-2019-324).

Acknowledgments: Thanks to Alex Campbell, Michael Paye, and two anonymous reviewers for their invaluable comments on an earlier draft of this piece, and to Rachel Sykes for giving me the opportunity for further helpful feedback on this work at a talk for the Centre for Contemporary Literature at University of Birmingham.

Conflicts of Interest: The author declares no conflict of interest.

\section{References}

Anand, Nikhil. 2017. Hydraulic City: Water and the Infrastructures of Citizenship in Mumbai. Durham: Duke University Press.

Bacigalupi, Paulo. 2015. The Water Knife. London: Orbit.

13 I am grateful to Sharae Deckard and Daniel Hartley for prompting me to think through this problem.

14 The book concludes with verse 35:9 of the Qu'ran, '[a]nd it is Allah who sends the winds, and they stir the clouds, and We drive them to a dead land and give life thereby to the earth after its lifelessness. Thus is the resurrection.' 
Bakker, Karen, and David Henson. 2000. Privatising Water: BoTT and Hydropolitics in the New South Africa. South African Geographical Journal 82: 3-12. [CrossRef]

Bambini, Karl Kristian Swane. 2019. Oil and Calories: Energy Paradigms in Paolo Bacigalupi's Ship Breaker and 'The Calorie Man. Open Library of Humanities 5: 57. [CrossRef]

Banerjee, Sarnath. 2015. All Quiet in Vikaspuri. Noida: HarperCollins.

Belcher, Oliver, Patrick Bigger, Ben Neimark, and Cara Kennelly. 2019. Hidden Carbon Costs of the 'Everywhere War': Logistics, Geopolitical Ecology, and the Carbon Boot-Print of the US Military. Transactions of the Institute of British Geographers. [CrossRef]

Birkinshaw, Matt. 2017. Murky Water: Infrastructure, Informality and Reform in Delhi. London School of Economics and Political Science (LSE). Available online: https://core.ac.uk/download/pdf/160748760.pdf (accessed on 5 December 2019).

Blackmore, Lisa. 2018. Colonizing Flow: Hydropower and Post-Kinetic Assemblages in the Orinoco Basin. In Natura: Environmental Aesthetics After Landscape. Edited by Jens Andermann, Lisa Blackmore and Dayron Carrillo Morell. Chicago: University Of Chicago Press, pp. 171-97.

Boast, Hannah. 2020. 'Borrowed waters: Water crisis and water justice in Rita Wong's undercurrent'. Textual Practice. [CrossRef]

Boast, Hannah. 2020. Hydrofictions: Water, Power and Politics in Israeli and Palestinian Literature. Edinburgh: Edinburgh University Press.

Bollain, Icíar. 2010. Even the Rain. Brooklyn: Vitagraph Films.

Burstyn, Varda. 2005. Water Inc.. London and New York: Verso.

Cascão, Ana Elisa, Alvar Closas, Emanuele Fantini, Goitom Gebreleul, Tobias Ide, Guy Jobbins, and Rémy Kiny. 2018. Why Are Water Wars Back on the Agenda? And Why We Think It's a Bad Idea! Entitle Blog. March 22. Available online: https://entitleblog.org/2018/03/22/why-are-water-wars-back-on-the-agenda-and-why-wethink-its-a-bad-idea/ (accessed on 5 December 2019).

Castree, Noel, and Bruce Braun, eds. 2001. Social Nature: Theory, Practice, and Politics. Malden: Blackwell Publishers.

Chacko, Priya. 2019. Marketizing Hindutva: The State, Society, and Markets in Hindu Nationalism. Modern Asian Studies 53: 377-410. [CrossRef]

Dajani, Muna. 2014. Drying Palestine: Israel's Systemic Water War. Al-Shabaka. September 4. Available online: https://al-shabaka.org/briefs/drying-palestine-israels-systemic-water-war/ (accessed on 28 July 2020).

Deckard, Sharae. 2019. Water Shocks: Neoliberal Hydrofiction and the Crisis of 'Cheap Water'. Atlantic Studies 16: 108-25. [CrossRef]

Dunn, Emma. 2016. Rape and Reconciliation: A Comparison of Karen Jayes' For the Mercy of Water and Emma Ruby-Sachs' The Water Man's Daughter. Safundi 17: 87-100. [CrossRef]

Efron, Shira, Jordan Fischbach, Ilana Blum, Rouslan Karimov, and Melinda Moore. 2018. The Public Health Impacts of Gaza's Water Crisis: Analysis and Policy Options. Santa Monica: RAND Corporation.

Fletcher, Robert. 2012. Capitalizing on Chaos: Climate Change and Disaster Capitalism. Ephemera 12: 97-112.

Forchtner, Bernhard, ed. 2019. The Far Right and the Environment: Politics, Discourse and Communication. Boca Raton: CRC Press.

Gandy, Matthew. 2004. Rethinking Urban Metabolism: Water, Space and the Modern City. City 8: $363-79$. [CrossRef]

Gavron, Assaf. 2010. Hydromania [Synopsis, Review Quotes, Sample Translation], Translated by Assaf Gavron. Unpublished manuscript.

Gilmartin, David. 1994. Scientific Empire and Imperial Science: Colonialism and Irrigation Technology in the Indus Basin. The Journal of Asian Studies 53: 1127-49. [CrossRef]

Harris, Ashleigh. 2020. Afropolitanism and the Novel: De-Realizing Africa. Abingdon: Routledge.

Harvey, David. 1993. The Nature of Environment: Dialectics of Social and Environmental Change. Socialist Register 29: 1-51.

Itäranta, Emmi. 2014. Memory of Water. London: HarperVoyager.

Jayes, Karen. 2012. For the Mercy of Water [Ebook]. Cape Town: Penguin.

Johnson, Bryan Stanley. 2013. Albert Angelo. London: Picador. First published 1964.

Kahiu, Wanuri. 2009. Pumzi. New York: Focus Features.

Kaika, Maria. 2005. City of Flows: Modernity, Nature, and the City. London: Routledge. 
Kaika, Maria, and Erik Swyngedouw. 2000. Fetishizing the Modern City: The Phantasmagoria of Urban Technological Networks. International Journal of Urban and Regional Research 24: 120-38. [CrossRef]

Kaminski, Volker. 2009. Assaf Gavron's Novel ‘Hydromania’: Provocative Plot. Qantara.De. April 24. Available online: https://en.qantara.de/content/assaf-gavrons-novel-hydromania-provocative-plot (accessed on 5 December 2019).

Kaplan, Robert D. 1994. The Coming Anarchy. The Atlantic. February 1. Available online: https://www.theatlantic. com/magazine/archive/1994/02/the-coming-anarchy/304670/ (accessed on 5 December 2019).

Klein, Naomi. 2007. The Shock Doctrine: The Rise of Disaster Capitalism. London: Macmillan.

Linton, Jamie. 2010. What Is Water?: The History of a Modern Abstraction. Vancouver: UBC Press.

Madan, Anuja. 2018. Slow Violence and Water Racism in Sarnath Banerjee's All Quiet in Vikaspuri. South Asian Review 39: 125-43. [CrossRef]

Malka, Inbal. 2008. To the Last Drop. Haaretz. December 8. Available online: http://www.haaretz.com/news/tothe-last-drop-1.259092 (accessed on 5 December 2019).

McCloud, Scott. 1993. Understanding Comics: The Invisible Art. New York: Harper Collins.

McDonald, David Alexander, and Greg Ruiters, eds. 2005. The Age of Commodity: Water Privatization in Southern Africa. London: Earthscan.

McDougall, Russell. 2012. Caribbean water and hydro-piracy. Kunapipi 34: 191-99.

McKinley, Dale T. 2005. The Struggle against Water Privatisation in South Africa. In Reclaiming Public Water: Achievements, Struggles and Visions from around the World. Edited by Brid Brennan, Olivier Hoedman, Satoko Kishimoto, Philipp Terhorst and Belén Balanyá. Amsterdam: Transnational Institute and Corporate Europe Observatory, pp. 181-89.

Mekonnen, Mesfin M., and Arjen Y. Hoekstra. 2016. Four Billion People Facing Severe Water Scarcity. Science Advances 2: e1500323. [CrossRef]

Menga, Filippo, and Erik Swyngedouw. 2018a. States of Water. In Water, Technology and the Nation-State. Edited by Filippo Menga and Erik Swyngedouw. Abingdon: Routledge, pp. 1-18.

Menga, Filippo, and Erik Swyngedouw, eds. 2018b. Water, Technology and the Nation-State. Abingdon: Routledge. Miller, George. 2015. Mad Max: Fury Road. Burbank: Warner Bros. Pictures.

Miller, Giulia F. 2013. The Rise of the Israeli Eco-Thriller: Assaf Gavron's Hydromania (2008) and Adi Ben-Artzi's Mezimat Effect Ha-Hamamah (The Global Warming Conspiracy, 2010). New York: The Jewish Theological Seminary, Available online: https://www.academia.edu/4227425/The_Rise_of_the_Israeli_Eco-Thriller_ Assaf_Gavron_s_Hydromania_2008_and_Adi_Ben-Artzi_s_Mezimat_Effect_Ha-Hamamah_The_Global_ Warming_Conspiracy_2010_(accessed on 5 December 2019).

Moore, Jason W. 2015. Capitalism in the Web of Life: Ecology and the Accumulation of Capital. New York: Verso.

Mukherjee, Upamanyu Pablo. 2010. Postcolonial Environments: Nature, Culture and the Contemporary Indian Novel in English. Basingstoke: Palgrave Macmillan.

Nixon, Rob. 2011. Slow Violence and the Environmentalism of the Poor. Cambridge: Harvard University Press.

Otter, Chris. 2002. Making Liberalism Durable: Vision and Civility in the Late Victorian City. Social History 27: 1-15. [CrossRef]

Perry, Laura. 2018. Anthroposcenes: Towards an Environmental Graphic Novel. C21 Literature 6. [CrossRef]

Reisner, Mark. 1986. Cadillac Desert. New York: Penguin.

Rivera, Alex. 2008. Sleep Dealer. Los Angeles: Maya Entertainment.

von Schnitzler, Antina. 2008. Citizenship Prepaid: Water, Calculability, and Techno-Politics in South Africa. Journal of Southern African Studies 34: 899-917. [CrossRef]

Scott, James C. 1998. Seeing like a State: How Certain Schemes to Improve the Human Condition Have Failed. London: Yale University Press.

Seeger, Sean, and Daniel Davison-Vecchione. 2019. Dystopian Literature and the Sociological Imagination. Thesis Eleven 155. [CrossRef]

Selby, Jan. 2003. Water, Power and Politics in the Middle East: The Other Israeli-Palestinian Conflict. London: I. B. Tauris.

Selby, Jan, and Clemens Hoffmann. 2012. Water Scarcity, Conflict, and Migration: A Comparative Analysis and Reappraisal. Environment and Planning C: Government and Policy 30: 997-1014. [CrossRef]

Selby, Jan, and Clemens Hoffmann. 2014a. Beyond Scarcity: Rethinking Water, Climate Change and Conflict in the Sudans. Global Environmental Change 29: 360-70. [CrossRef] 
Selby, Jan, and Clemens Hoffmann. 2014b. Rethinking Climate Change, Conflict and Security. Geopolitics 19: 747-56. [CrossRef]

Smith, Neil. 2008. Uneven Development: Nature, Capital, and the Production of Space, 3rd ed. Athens: University of Georgia Press.

Stracher, Cameron. 2011. The Water Wars. Naperville: Sourcebooks.

Sultana, Farhana. 2009. Fluid Lives: Subjectivities, Gender and Water in Rural Bangladesh. Gender, Place E Culture 16: $427-44$.

Suvin, Darko. 2016. Metamorphoses of Science Fiction: On the Poetics and History of a Literary Genre. Edeted by Gerry Canavan. Bern: Peter Lang.

Swyngedouw, Erik. 2004. Social Power and the Urbanization of Water: Flows of Power. Oxford: Oxford University Press.

Swyngedouw, Erik. 2005. Dispossessing $\mathrm{H}_{2}$ O: The Contested Terrain of Water Privatization. Capitalism Nature Socialism 16: 81-98. [CrossRef]

Swyngedouw, Erik. 2015. Liquid Power: Contested Hydro-Modernities in Twentieth-Century Spain. Cambridge: MIT Press.

Trexler, Adam. 2015. Anthropocene Fictions: The Novel in a Time of Climate Change. Charlottesville: University of Virginia Press.

Walton, Brett. 2018. Cape Town's Harrowing Journey to the Brink of Water Catastrophe. Circle of Blue. Available online: https://www.circleofblue.org/2018/world/cape-towns-harrowing-journey-to-the-brink-ofwater-catastrophe/ (accessed on 4 August 2020).

Warwick Research Collective (WReC). 2015. Combined and Uneven Development: Towards a New Theory of World-Literature. Liverpool: Liverpool University Press.

Watts, Richard. 2007. Contested Sources: Water as Commodity/Sign in French Caribbean Literature. Atlantic Studies 4: 87-101. [CrossRef]

Wenzel, Jennifer. 2020. The Disposition of Nature: Environmental Crisis and World Literature. New York: Fordham University Press.

Wittfogel, Karl August. 1957. Oriental Despotism, a Comparative Study of Total Power. New Haven: Yale University Press.

Worster, Donald. 1985. Rivers of Empire: Water, Aridity, and the Growth of the American West. Oxford: Oxford University Press.

Yosef-Paz, Netta Bar. 2018. Hebrew Dystopias: From National Catastrophes to Ecological Disasters. Israel Studies Review 33: 66-84. [CrossRef]

(C) 2020 by the author. Licensee MDPI, Basel, Switzerland. This article is an open access article distributed under the terms and conditions of the Creative Commons Attribution (CC BY) license (http://creativecommons.org/licenses/by/4.0/). 